\title{
Aerobic stability of sugar cane silages with a novel strain of Lactobacillus sp. isolated from sugar cane ${ }^{1}$
}

\section{Carla Luiza da Silva Ávila², José Cardoso Pinto ${ }^{3}$, Dâmiany Pádua Oliveira ${ }^{3}$, Rosane Freitas Schwan 4}

\author{
1 Project financed by CNPq. \\ 2 Programa de Pós-doutorado em Zootecnia - UFLA. \\ ${ }^{3}$ Departamento de Zootecnia - UFLA. \\ ${ }^{4}$ Departamento de Biologia - UFLA.
}

\begin{abstract}
The objective of this research was to evaluate the effect of the addition of two Lactobacillus strains on the aerobic stability of the sugar cane (Saccharum spp.) silages. The experiment was carried out in a completely randomized design with three replicates in split-plot in time scheme, so that the treatments (silages without inoculant and with novel strain or commercial inoculants) were randomized on plot and in times of aerobic evaluation of the silages (zero, two, four, and six days after the opening of the silos) as subplots. The loss of stability of silages was continuous during the time of aerobic exposure. Inoculants influenced the changes in populations of lactic acid bacteria and yeasts and in the ammoniacal nitrogen, acetic acid and ethanol concentrations. The dry matter, crude protein, soluble carbohydrates contents and $\mathrm{pH}$ values showed similar changes in all three silages studied. A linear increase in crude protein content and $\mathrm{pH}$ values and decrease in the soluble carbohydrates content were observed. The dry matter contents increased to a maximum of $335 \mathrm{~g} / \mathrm{kg}$ on fresh matter at four days, followed by reduction after six days. The results showed that the use of inoculants is recommended because it promoted higher production of acetic and propionic acids, reducing the population of yeast and, therefore, improving the aerobic stability of silages.
\end{abstract}

Key Words: acetic acid, fermentation, lactic acid, microbiology

\section{Introduction}

The susceptibility of a silage to the aerobic deterioration is an important factor for it is directly related to its quality and nutritive value. When silage is exposed to air, increase in temperature and $\mathrm{pH}$ may occur, resulting in soluble carbohydrates loss and fermentation of the microbial metabolism products which will reduce its quality and digestibility (Holzer et al., 2003). In addition, toxic products may be produced by fungi and by other bacteria, allowing the occurrence of harm to health (Driehuis et al., 2008).

The sugar cane ensiling (Saccharum spp.) is an operational solution, for it eliminates the daily cut, which enables more uniform coppicing and greater effectiveness of the cultural tracts. However, the process of production and supply of the sugar cane ensiling to the animals involves considerable losses (Balieiro Neto et al., 2007). The main losses during the fermentation of the sugar cane occur in the anaerobic phase, as a result of the yeast growth, and are not inhibited by the lowering of the $\mathrm{pH}$ and anaerobiosis.

The use of inoculants containing lactic acid bacteria (LAB) capable of producing other acids, such as acetic or propionic acid, which are more effective in the inhibition of the filamentous fungi and yeasts growth (Moon et al., 1983) may increase their aerobic stability. The effectiveness of the bacteria of the Lactobacillus buchneri species in improving the aerobic stability of the silages of forage of temperate climate was proved by Kleinschmit \& Kung Junior (2006). In silages of sugar cane, heterofermentative bacteria, mainly the L. buchneri, have been tested in the past years aiming to improve both the anaerobic and the aerobic phases of fermentation (Zopollatto et al., 2009).

The evaluation of the aerobic stability of the silages by means of the changes in temperature is an indirect measure of the growth of the deteriorating microorganisms, especially filamentous fungi and yeasts (Holzer et al., 2003). There are other ways of evaluating the aerobic stability of the silages such as visual appearance, changes in $\mathrm{pH}$ and production of $\mathrm{CO}_{2}$, evaluation of the population of microorganisms and changes in the chemical composition. The conduction of this study aimed to evaluate the effect of the addition of microbial inoculants on the chemical, bromatological and microbiological changes in the sugar cane silages. 


\section{Material and Methods}

The experiment was conducted in the Departamentos de Zootencia e Biologia of the Universidade Federal de Lavras (UFLA), Lavras, Minas Gerais, Brazil. The sugar cane used in the experiment was picked from a sugar cane plantation established in an area, property of UFLA, RB72454 variety, at regrowth age of 12 months, in the drought season (June), when it presented $18^{\circ}$ Brix. The harvest was manual, and then, the sugar cane was chopped in a stationary chopper without detrashing, providing particles measuring around $20 \mathrm{~mm}$ for the production of silage.

Inoculants were previously prepared in the Microbiology Lab of the Departamento de Biologia of UFLA. The new strain of Lactobacillus, denominated experimental, consisted of the bacterium biochemically classified as Lactobacillus buchneri (UFLA SIL 72), isolated from a sugar cane silage (Ávila et al., 2009a), while the commercial inoculants employed were the 11A44TM Pioneer (Pioneer Hi-Bred International, Inc., Des Moines, IA, USA), which contain the L. buchneri bacterium in the concentration of $10^{11} \mathrm{ufc} / \mathrm{g}$ of the product.

The commercial inoculants were added according to the recommendation of the producer of $5 \mathrm{log}$ ufc/g of forage. For that, $0.003 \mathrm{~g}$ of the inoculants were weighed, mixed with $80 \mathrm{~mL}$ of sterile distilled water and, afterwards, sprinkled over the forage at the moment of ensiling. In order to allow both of them to be added to the same viable cells concentration, the count of the number of these in the experimental inoculants was conducted by means of a plating in MRS (Mann Rogosa Sharpe) medium. Initially, the microorganism was cultivated in tubes containing $2 \mathrm{~mL}$ of MRS broth for 24 hours; next, it was transferred to tubes containing $10 \mathrm{~mL}$ of MRS broth for another 24 hour period and, finally, transferred to Erlenmeyer with $250 \mathrm{~mL}$ of MRS broth and cultivated for 24 hours. Sequentially, the count of the cell number was conducted, obtaining a result of $9 \log \mathrm{cfu} / \mathrm{mL}$ of the broth. Then, for each silo $0.3 \mathrm{~mL}$ of the broth present in the Erlenmeyer was extracted, which was afterwards mixed to $80 \mathrm{~mL}$ of distilled sterile water and sprinkled over $3 \mathrm{~kg}$ of forage to be ensiled. In the end, the experimental inoculant was inoculated in a concentration of $5 \log \mathrm{cfu} / \mathrm{g}$ of forage.

The chopped forage was ensiled in PVC silos of $10 \mathrm{~cm}$ in diameter and $80 \mathrm{~cm}$ in height, adapted with Bunsen type valve with capacity for 2.5 to $3 \mathrm{~kg}$ of forage, in the approximate density of $600 \mathrm{~kg}$ of forage per $\mathrm{m}^{3}$. Prior to ensiling, samples of forage were taken, both pure and with additives, which were forwarded to the Laboratório de Pesquisa Animal of the Departamento de Zootecnia of UFLA for analysis of the chemical composition and buffer capacity (Table 1 ). For the conduction of the analysis, samples were oven-dried $\left(65^{\circ} \mathrm{C}\right)$, ground in Willey type mill with sieve of mesh 30 and stored in plastic pots for the determination of the dry matter (DM) and crude protein (CP) rate, according to the methods recommended by AOAC (1990); neutral detergent fiber (NDF) and acid detergent fiber (ADF), according to techniques described by Silva (1990); soluble carbohydrates (SC), according to methodology of Bailey (1967), modified by Valadares Filho (1981); and buffer capacity, according to Playne \& McDonald (1966).

The inoculants previously prepared were mixed in the forage at the moment of ensiling, with the help of a sprinkler (one for each silage), trying to add to the control silage only the sterile distilled water, in the same amount of water added to the inoculants $(80 \mathrm{~mL})$. The forage was manually compacted in the silos with the help of an iron bar, so that it was stored in room temperature and protected from the day light and rain.

After a 90-day period of storage, the silos were open and, from each one, three samples were taken. From these samples, a part (100 g) was put in plastic bags properly identified and frozen. Afterwards, the juice was extracted, with a hydraulic press, for the determination of the ammoniacal nitrogen content, in percentage of the total nitrogen $\left[\mathrm{NH}_{3}-\mathrm{N}\right.$ (g/kg N total)], and of the acetic, propionic, butyric and lactic acids, by gaseous chromatography

Table 1 - Chemical composition and buffer capacity of the sugar cane before ensiling

\begin{tabular}{lccc}
\hline & & Sugar cane \\
\cline { 2 - 4 } & Without inoculant & Experimental inoculant & Commercial inoculant \\
\hline Dry matter (g/kg NM) & 293 & 299 & 295 \\
Crude protein (g/kg DM) & 34 & 52 & 29 \\
Neutral detergent fiber (g/kg DM) & 578 & 319 & 562 \\
Acid detergent fiber (g/kg DM) & 318 & 248 & 315 \\
Hemicellulose (g/kg DM) & 259 & 293 & 247 \\
Soluble carbohydrates (g/kg DM) & 300 & 10.6 & 299 \\
Buffer capacity (Emg NaOH/100g DM) & 11.0 & 10.4 \\
\hline
\end{tabular}

DM - dry matter; NM - natural matter. 
(AOAC, 1980). In the cromatographical analysis, the Shimadzu GC17a cromatograph was used; Capillary column $(30 \mathrm{~m} \times 0.025 \mathrm{~mm})$ with initial temperature at $90 \mathrm{p} \mathrm{C}$ and final at $180 \mathrm{p} \mathrm{C}$, pressure at 22 and flux at 20 (AOAC, 1980).

The other sample of $80 \mathrm{~g}$ was collected and put in a bottle containing $720 \mathrm{~mL}$ of sterile peptonated water (1\% peptone), sterilized (at $121 \mathrm{p} \mathrm{C/15}$ minutes) and agitated for 20 minutes. From the obtained extract, decimal dilutions from $10^{-1}$ to $10^{-6}$ for evaluation of the populations of $\mathrm{LAB}$, yeasts and filamentous fungi were prepared, according to Ávila et al. (2009a). A subsample of $10 \mathrm{~g}$ was also extracted for the preparation of the extracts and reading of the $\mathrm{pH}$, in DIGIMED $^{\circledR}$ DM 20 potentiometer. A third sample of approximately $100 \mathrm{~g}$ was extracted for analysis of the contents of DM, CP and soluble carbohydrates, according to previously described techniques.

All the remaining silage content (2.0 to $2.5 \mathrm{~kg}$ ) was packed in plastic buckets of approximately $5.0 \mathrm{~kg}$, where it remained for six days. During the period in which the silages were kept in buckets, on days zero (opening of the silos), four and six, samples were taken for chemical, bromatological and microbiological analysis of the silages, through the same techniques previously described.

The design carried out was completely randomized, with three replications, applying the subdivided plot scheme, whereby the treatments (silages without inoculants, with experimental inoculants and with commercial inoculants) were randomized in the plots and the evaluation times (zero, two, four and six days after the opening of the silos), in the subplots. The data were statistically analyzed by the procedures of analysis of variance suggested by Steel et al. (1997) for the experiments in subdivided plots when the plots are measured in the time, using the SIVAR ${ }^{\circledR}$ software. Those treatments of qualitative nature (treatments for ensilage) were compared by the Scott-Knott test at $95 \%$ probability level, and the ones of quantitative nature (evaluation times) were submitted to the regression study.

\section{Results and Discussion}

For the LAB and yeasts counts, there was significant interaction between inoculants and the times of evaluation in the silages after the opening of the silos, which demonstrates that the additives used at the moment of ensiling influenced the population of these microorganisms in the aerobic phase. At the moment of the opening of the silos (zero time), the inoculated silages showed higher LAB population (Table 2). After two days, there was reduction of these microorganisms in the silages with commercial inoculants, showing values similar to the one of the control silage. On days two and four, the silage with experimental inoculant showed a greater LAB count. After six days, however, the count was similar for the three treatments (Table 2). In general, the LAB populations in the three silages varied from 8.49 to $10.07 \mathrm{log}$ of the $\mathrm{cfu} / \mathrm{g}$ of silage. The LAB populations were high since the moment of the opening of the silos. However, no studies were found evaluating the LAB population along the aerobic exposure. Since some microorganisms which do not belong to this group may grow in the MRS medium used for the LAB

Table 2 - Microbial population of the sugar cane silages after opening of the silos

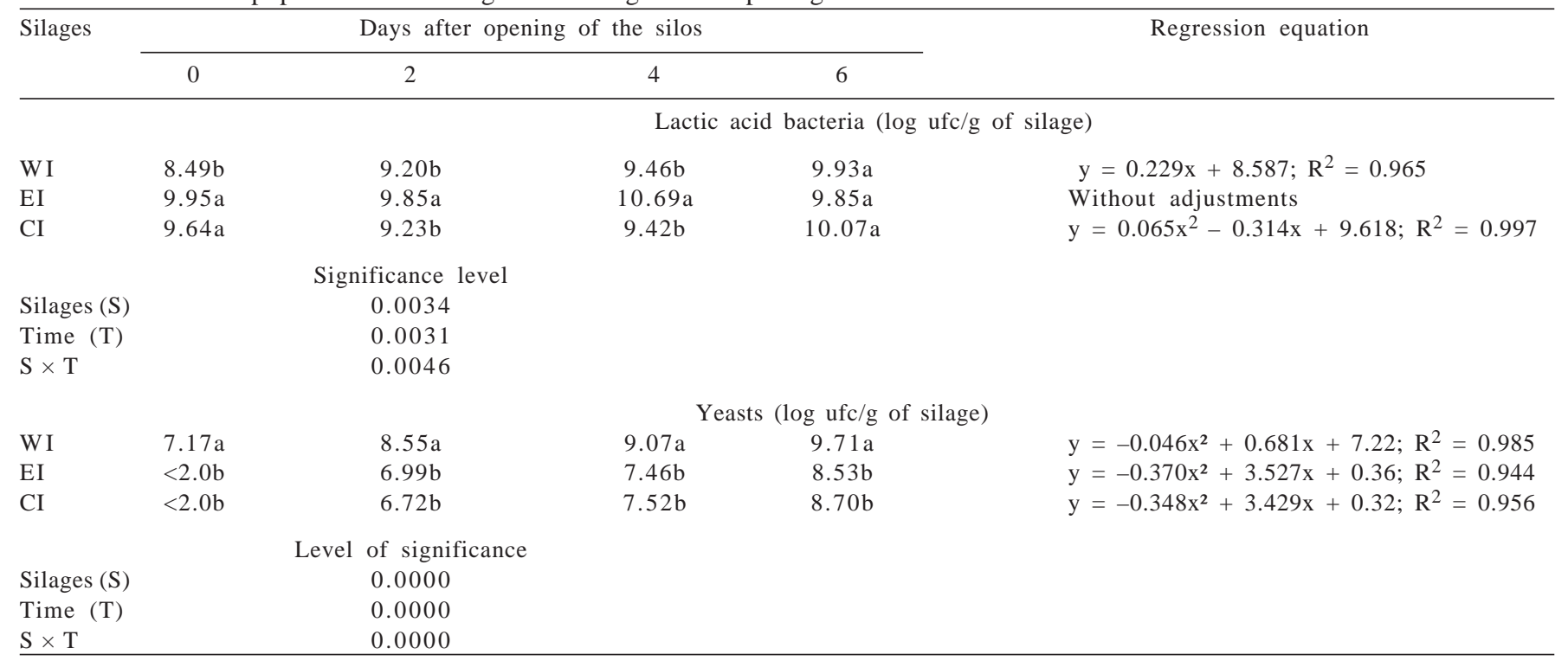

WI - without inoculant; EI - experimental inoculant; CI - commercial inoculant.

Means followed by different letters in the columns statistically differ $(\mathrm{P}<0.05)$ by Scott-Knott test.

R. Bras. Zootec., v.41, n.2, p.249-255, 2012 
count, this count could be overestimated. However, Ávila et al. (2009a), using the same medium, observed that the 72 strains isolated in the sugar cane silage, all belonged to the Lactobacillus gender.

The growth profiles of the yeasts in the three silages showed quadratic behavior after the opening of the silos (Table 2). At the moment of the opening, the count of the yeasts in the inoculated silages was below the minimum level for detection (2.0 log cfu/g). However, these increased rapidly until a maximum population of $8.49 \mathrm{log} \mathrm{cfu} / \mathrm{g}$ of silage at four days of aerobic exposure. However, this population did not reach the yeast count of the control silage that, initially, was already high (7.2 log cfu/g), increasing even more up to a maximum population of $9.5 \mathrm{log}$ cfu/g of silage (Table 2). Increases in the yeast count in silages are expected since the aerobic conditions propitiate the multiplication of the cells. In the inoculated silages, this increase happened more slowly due to the higher content of acetic acid.

The filamentous fungi population was below the minimum detectable level (2.0 log cfu/g of silage) during the six-day period when the sugar cane silages were exposed to air. Corroborating Ávila et al. (2010) and Bravo-Martins et al. (2006), the growth of these microorganisms was not visually observed in any of the studied silages.

At the opening of the silos (zero time of aerobic evaluation) butyric acid was not detected and only traces of lactic acid were detected (Table 3). High concentrations of lactic acid were expected in the silages due to the high concentration of soluble carbohydrates. However, this did not happen in any of the silages. Due to the longer period of fermentation (90 days), this acid may have been consumed by lactate assimilating yeasts (McDonald et al., 1991) or even by heterofermentative bacteria such as those of the L. buchneri or L. brevis species (Oude Elferink et al., 2001).

The propionic acid was detected at the opening of the silos (zero time of the aerobic stability evaluation), in the silages without inoculant and inoculated with experimental inoculant (Table 3). In the silage of experimental inoculants, the propionic acid content was considered high in relation

Table 3 - Concentrations of acetic, propionic and lactic acid, and ethanol $(\mathrm{g} / \mathrm{kg}$ in the $\mathrm{DM})$ in the sugar cane silages without inoculant and with experimental and commercial inoculants at the moment of silo opening

\begin{tabular}{lcccc}
\hline Silages & Acetic & Propionic & Lactic & Ethanol \\
\hline Without inoculant & $17.4 \mathrm{c}$ & $4.7 \mathrm{~b}$ & $0.02 \mathrm{a}$ & $61.4 \mathrm{c}$ \\
Experimental inoculant & $40.7 \mathrm{~b}$ & $14.4 \mathrm{a}$ & $0.00 \mathrm{a}$ & $21.1 \mathrm{a}$ \\
Commercial inoculant & $43.1 \mathrm{a}$ & $0.0 \mathrm{c}$ & $0.02 \mathrm{a}$ & $28.5 \mathrm{~b}$ \\
\hline \multicolumn{4}{l}{ Means followed by the same letter in the column do not differ (P>0.05) by Scott- }
\end{tabular}
Knott test. to the values normally found in silages. Ávila et al. (2009b) studied the profile of the volatile fatty acids of LAB isolates of sugar cane silage, in conjoined fermentation with yeasts, in sugar cane broth. These authors observed the significant productions of propionic acid by this isolate, showing that, in a way, this acid was produced during the fermentation.

There are still few published papers which evaluate the profile of the volatile fatty acids in sugar cane silages, in Brazil. Amaral et al. (2009) found concentrations of 13 and $2 \mathrm{~g} / \mathrm{kg}$ in the DM of acetic acid and butyric acid, respectively, in sugar cane silages without additives. In the research of Mendes et al (2009), the contents of acetic acid were high (41 to $57.6 \mathrm{~g} / \mathrm{kg}$ in the DM) and similar to those values found in the silages inoculated at the moment of silo opening (Table 3).

For the concentrations of acetic acid and ethanol a significant interaction between the inoculants and the evaluation times was observed (Table 4). In relation to the acetic acid, a reduction in its concentration after the opening of the silos was observed in the three treatments (Table 4). In the silages without inoculants and with experimental inoculants, this reduction happened in a linear form, as from 7.1 and $6.8 \mathrm{~g} / \mathrm{kg}$ in the DM, respectively, per day. On the other hand, for the silages with commercial inoculants, a quadratic response was observed, with a maximum concentration of acetic acid of $47.2 \mathrm{~g} / \mathrm{kg}$ in the DM at 1.35 days, reducing to zero concentration on day six (Figure 1). The reduction of the acetic acid may have occurred either by volatilization of this acid or by the use by bacteria of the acetic acid. According to Spoelstra et al. (1988), after the use of ethanol, these bacteria can metabolize the acetic acid completely as well as the lactic acid at $\mathrm{CO}^{2}$ and water, causing intense increase in the $\mathrm{pH}$.

Generally, it was observed that the products of the microbial metabolism produced during the fermentation are rapidly lost after the aerobic exposure. The data show that in the inoculated silages, the contents of acetic acid remain higher up to the four exposure days, featuring the silages with commercial inoculants (Table 4). In the latter, the acetic acid may have been the main responsible for the slower growth of the yeast in the period of post-opening of the silos. In the silages with experimental inoculants, the greater propionic acid content (Table 3) at the moment of opening of the silos may have contributed for the lesser growth of the yeasts (Table 4 ).

The concentrations of ethanol in the silages without inoculant and with experimental and commercial inoculants reduced to minimum values near zero, respectively, at 4.4; 5.0 and 4.5 days after the opening of the silos (Table 4). 
These data show that the ethanol is rapidly lost after the opening, resulting in losses of DM in the silages.

After the opening of the silos, significant variations in the contents of DM, CP, SC, and NH3 and in the values of $\mathrm{pH}$ were noticed. For the contents of DM, CP, and SC, and values of $\mathrm{pH}$, no significant interaction between inoculants and time of air exposure was observed. Therefore, the treatments showed the same behavior during the period of evaluation (Figures 1 and 2).

After the opening of the silos, a quadratic response of the DM contents in the sugar cane silages was noticed due to the time of aerobic exposure, with increase up to the maximum value of $335 \mathrm{~g} / \mathrm{kg}$ in the natural matter (NM) on day four, followed by reduction until day six (Figure 1). For the contents of CP, a linear increase along the time was noticed, with increase of $2 \mathrm{~g} / \mathrm{kg}$ in the DM per day (Figure 1).
The increase of the contents of DM resulted, mainly, in the dehydration of the material that stayed six days exposed to the air. At approximately four days, there was a tendency of reduction, which may be explained by the consumption of the SC and by the formation of the so-called water metabolism (Woolford, 1984). Other authors also noticed increase followed by fall in the contents of DM of sugar cane silages (Baliero Neto et al., 2009) and of mombaça grass (Ávila et al., 2009c). The elevation in the contents of CP was not expected. However, a probable explanation would be by means of the synthesis of the microbial protein, since after the opening of the silos the microbial growth was intense, or the increase of the DM content, since the protein contents are calculated based on the DM contents. Baliero Neto et al. (2007) noticed the increase in the CP contents of sugar cane silages from 32 to $43 \mathrm{~g} / \mathrm{kg}$ in the DM at nine days

Table 4 - Concentrations of acetic acid and ethanol in the sugar cane silages after opening of the silos

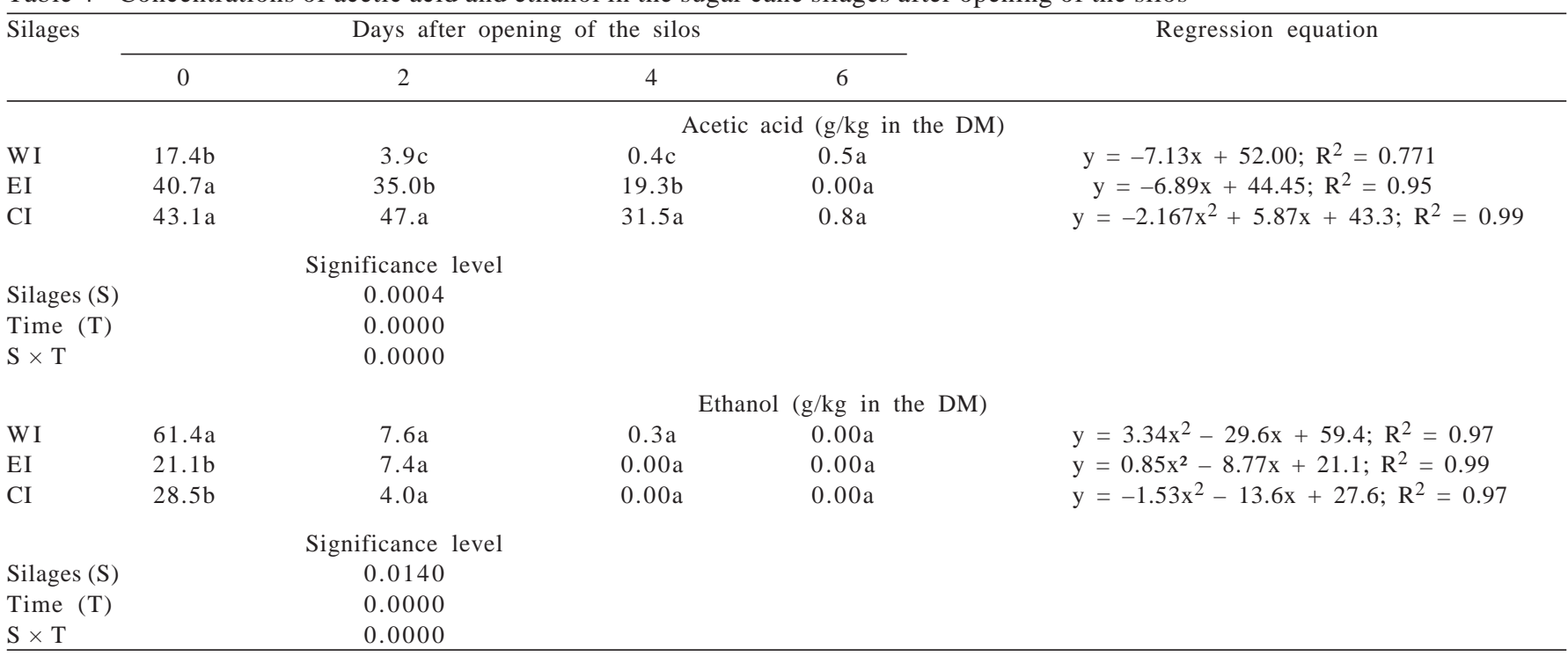

WI - without inoculant; EI - experimental inoculant; CI - commercial inoculant.

Means followed by different letters in the columns, differ statistically $(\mathrm{P}<0.05)$ by Scott-Knot test.

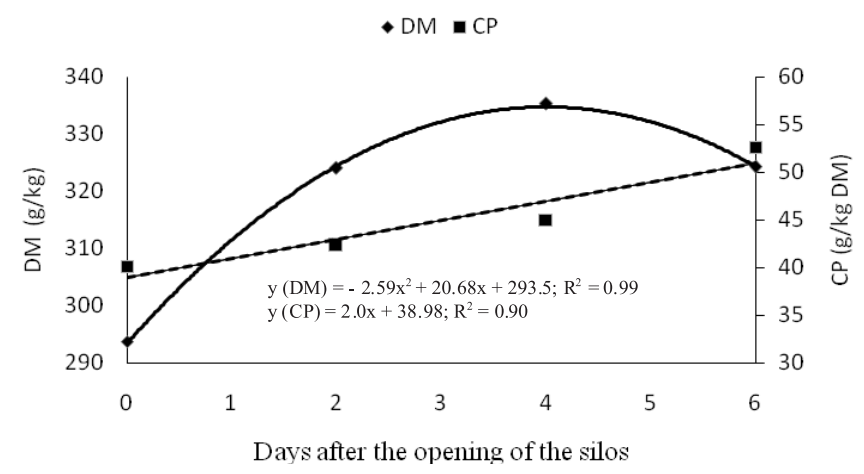

Figure 1 - Contents of dry matter (DM) in natural matter and crude protein (CP) (mean of the times) of sugar cane silages after the opening of the silos.

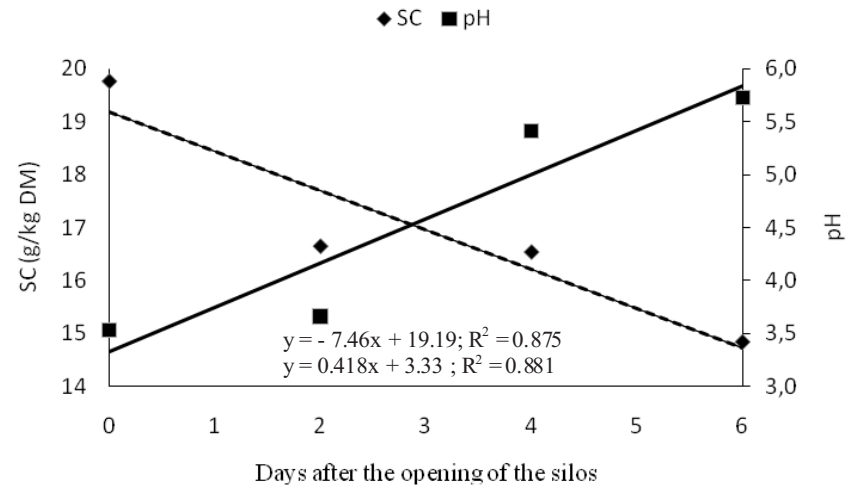

Figure 2 - Contents of soluble carbohydrates (SC) and values of $\mathrm{pH}$ (mean of the times) of the sugar cane silages after the opening of the silos. 
of aerobic exposure. According to the authors, this increase resulted from the consumption of soluble carbohydrates by yeasts during the fermentation and, after the opening of the silos, a proportional increase of the contents of CP might have happened.

In relation to the concentration of SC, there was a reduction of $7.46 \mathrm{~g} / \mathrm{kg}$ in the DM per day, after the opening of the silos, until day six of the aerobic exposure (Figure 2). The contents of soluble carbohydrates (mean of the times) of the inoculated silages were similar to one another and superior to the ones of the control silage (Table 5).

In relation to the values of $\mathrm{pH}$, the three silages showed similar behavior, with a linear increase of 0.4 per day during the period of evaluation of the aerobic stability (Figure 2). Baliero Neto et al. (2009) noticed different behavior in the increase of the values of $\mathrm{pH}$ after the opening of the silos and with additives. In the latter, the $\mathrm{pH}$ increased only after four days of exposure, whereby this behavior was correlated to the increase of temperature. Mendes et al. (2008) verified the effect of the inoculant over the losses of DM and the values of $\mathrm{pH}$ of the silages up to the fifth day of aerobic exposure, whereby the losses increased in both silages and remained inferior in the additivated silage.

In the inoculated silages, the population of yeasts was smaller. However, in these, it is possible that the population of LAB of the L. buchneri species was higher, resulting in an increase of the $\mathrm{pH}$. In addition, other bacteria which have the ability to metabolize the lactic acid, such as bacteria of the acetic acid, may have colonized the silage. In these silages, high concentrations of lactic acid were not detected. A possible explanation for this fact could be the use of this acid by microorganisms before the opening of the silos. With the increase of the $\mathrm{pH}$, other microorganisms, which were inactive in the silage, appear. In the case of inoculated silages, the increase in the $\mathrm{pH}$, resulting from the reduction of the organic acids, provided conditions for the development of the yeasts.

The variations in the concentrations of $\mathrm{NH}_{3}-\mathrm{N}$ showed a quadratic response due to the opening time of the silos,

Table 5 - Contents of soluble carbohydrates ( $\mathrm{g} / \mathrm{kg}$ in the DM) of the sugar cane silages without inoculant and with experimental and commercial inoculants after the opening of the silos

\begin{tabular}{lc}
\hline Silages & Means \\
\hline Without inoculant & $13.18 \mathrm{~b}$ \\
Experimental inoculant & $18.48 \mathrm{a}$ \\
Commercial inoculant & $19.19 \mathrm{a}$ \\
\hline Means followed by the same letter in the column do not differ $(\mathrm{P}>0.05)$ by Scott-
\end{tabular}

Knott test. with maximum values of 124,115 and $108 \mathrm{~g} / \mathrm{kg}$ of total $\mathrm{N}$ at 0.6 ; 1.3 ; and 1.4 days, respectively, for the control silages and for the silages inoculated with experimental and commercial inoculants (Table 6). An increase in the contents of $\mathrm{NH}_{3}-\mathrm{N}$ in the silages after the opening of the silos was expected due to the degradation of compounds nitrogenated by microorganisms of aerobic deterioration such as yeasts and some bacteria. This may really have happened. However, this behavior was not detected because ammonia is a very volatile component, disappearing during the air exposure.

Most of the studies that evaluate the aerobic stability of the sugar cane silages and others relate the aerobic stability to the increase of the temperature of $2{ }^{\circ} \mathrm{C}$ above the room temperature. What was observed in this study was a continuous loss of quality of the silages when these were exposed to the air and that the losses could be minimized by the inclusion of these inoculants.

\section{Conclusions}

The loss of the aerobic stability of the silages happens in a continuous form and the use of the inoculants significantly influences that process. Both strains of Lactobacillus tested showed positive and similar effects over the sugar cane silages. Their use is recommended, for it results in greater productions of acetic and propionic acids, reducing the population of yeasts and, thus, improving the aerobic stability of silages.

\section{Acknowledgements}

The authors thank CNPq, FAPEMIG, and CAPES, for the financial support.

\section{References}

AMARAL, R.C.; PIRES, A.V.; SUSIN, I. et al. Cana-de-açúcar ensilada com ou sem aditivos químicos: fermentação e composição química. Revista Brasileira de Zootecnia, v.38, n.8, p.1413-1421, 2009.

ASSOCIATION OF OFFICIAL AGRICULTURAL CHEMISTS AOAC. Official methods of analyses. 13.ed. Washington, D.C.: 1980. 1015p.

ASSOCIATION OF OFFICIAL AGRICULTURAL CHEMISTS AOAC. Official methods of analyses. 15.ed. Virginia: 1990, v.1, 648p.

ÁVILA, C.L.S.; PINTO, J.C.; FIGUEIREDO, H.C.P. et al. Effects of an indigenous and a commercial Lactobacillus buchneri strain on quality of sugar cane silage. Grass \& Forage Science, v.6, n.4, p.384-394, 2009a.

ÁVILA, C.L.S.; PINTO, J.C.; DUARTE, W.F. et al. Screening of lactic acid bacteria for sugarcane ensiling. In: INTERNATIONAL SILAGE CONFERENCE, 15., Madison, 2009. Proceedings.. Madison: USDA-ARS-WSU, 2009b. p.205-206. 
ÁVILA, C.L.S.; PINTO, J.C.; FIGUEIREDO, H.C.P. et al. Estabilidade aeróbia de silagens de capim-mombaça tratadas com Lactobacillus buchneri. Revista Brasileira de Zootecnia, v.38, n.5, p.779-7879, 2009c.

ÁVILA, C.L.S.; VALERIANO, A.R.; PINTO, J.C. et al. Chemical and microbiological characteristics of sugar cane silages treated with microbial inoculants. Revista Brasileira de Zootecnia, v.39, n.1, p.25-32, 2010.

BALIEIRO NETO, G.; SIQUEIRA, G.R.; REIS, R.A. et al. Óxido de cálcio como aditivo na ensilagem de cana-de-açúcar. Revista Brasileira de Zootecnia, v.36, n.5, p.1231-1239, 2007.

BALIEIRO NETO, G.; FERRARI JUNIOR, E.; NOGUEIRA, J.R. et al. Perdas fermentativas, composição química, estabilidade aeróbia e digestibilidade aparente de silagem de cana-de-açúcar com aditivos químico e microbiano. Pesquisa Agropecuária Brasileira, v.44, n.6, p.621-630, 2009.

BAILEY R.W. Quantitative studies of ruminant digestion of ingested plant carbohydrates from the reticulo-rumen. New Zealand Journal of Agricultural Research, v.10, n.1, p.15-32, 1967.

BRAVO-MARTINS, C.E.C.; CARNEIRO, H.; CASTRO-GOMES, R.J. et al. Chemical and microbiological evaluation of ensiled sugar cane with diferent additives. Brazilian Journal of Microbiology, v.37, n.4, p.499-504, 2006.

DRIEHUIS F.; SPANJER M.C.; SCHOLTEN J.M. et al. Occurrence of mycotoxins in feedstuffs of dairy cows and estimation of total dietary intakes. Journal of Dairy Science, v.91, n.11, p.4261-4271, 2008.

HOLZER, M.; MAYRHUBER, E.; DANNER, H. et al. The role of Lactobacillus buchneri in forage preservation. Trends in Biotechnology, v.21, n.6, p.283-287, 2003.

KLEINSCHMIT D.H.; KUNG JUNIOR, L. A meta-analysis of the effects of Lactobacillus buchneri on the fermentation and aerobic stability of corn and grass and small-grain silages. Journal of Dairy Science, v.89, n.10, p.4005-4013, 2006.
McDONALD, P.; HENDERSON, A.R.; HERON, S.J. Biochemistry of silage. 2.ed. Marlow: Chalcombe Publication, 1991. 340p. MENDES, C.Q.; SUSIN, I.; NUSSIO, L.G. et al. Efeito do Lactobacillus buchneri na fermentação, estabilidade aeróbia e no valor nutritivo de silagem de cana-de-açúcar. Revista Brasileira de Zootecnia, v.37, n.12, p.2191-2198, 2008.

MOON, N.J. Inhibition of the growth of acid-tolerant yeasts by acetate, lactate and propionate and their synergistic mixtures. Journal of Applied Bacteriology, v.55, n.3, p.454-460, 1983.

OUDE ELFERINK, S.J.W.H.; KROONEMAN, J.; GOTTSCHAL, J.A. et al. Anaerobic conversion of lactic acid to acetic acid and 1,2-propanediol by Lactobacillus buchneri. Applied and Environmental Microbiology, v.67, n.1, p.125-132, 2001.

PLAYNE, M.J.; McDONALD, P. The buffering constituints of herbage. Journal of Food Science and Agriculture, v.17, n.6, p.264-268, 1966.

SILVA, D.J. Análise de alimentos: métodos químicos e biológicos. Viçosa, MG: UFV, 1990. 166p.

SPOELSTRA, S.F.; COURTIN, M.G.; VAN BEERS, J.A.C. Acetic acid bacteria can initiate aerobic deterioration of whole crop maize silage. Journal Agricultural of Science, v.111, p.127-132, 1988

STEEL, R.G.D.; TORRIE, J.H.; DICKEY, D.A. Principles and procedures of statistcs a biometrical approach. 3.ed. Boston: WCB McGraw-Hill, 1997. 666p.

VALADARES FILHO, S.C. Digestibilidade aparente e locais de digestão da matéria seca, energia e carboidratos de feno de soja perene. 1981. 88f. Dissertação (Mestrado em Zootecnia) - Universidade Federal de Minas Gerais, Belo Horizonte, 1981.

WOOLFORD, M.K. The silage fermentation. New York: Marcel Dekker, 1984. 350p.

ZOPOLlATTO, M.; DANIEL, J.L.P.; NUSSIO, L.G. Aditivos microbiológicos em silagens no Brasil: revisão dos aspectos da ensilagem e do desempenho de animais. Revista Brasileira de Zootecnia, v.38, p.170-189, 2009. 